\title{
Annelerinin Görüsşlerine Göre DEHB Tanılı Çocukların Okullarda Karşılaştıkları Sorunlar
}

\author{
Problems Faced by Children Diagnosed with ADHD at the Schools According to the \\ Views of Mothers
}

\section{Elifcan CESUR ${ }^{* *}$ Aysel KÖKSAL AKYOL ${ }^{* * *}$}

Öz

$\mathrm{Bu}$ araştırmada, annelerinin görüşlerine göre DEHB tanılı çocukların okullarda karşılaştıkları sorunların belirlenmesi amaçlanmıştır. Ayrıca araştırmanın bir alt amacı da DEHB tanılı çocukları olan annelerin, çocukları ile evde yaşadıkları zorluklara ilişkin görüşlerinin incelenmesidir. Nitel modelde tasarlanan araştırmada durum deseni kullanılmıştır. Amaçlı örnekleme yöntemlerinden kartopu örnekleme ile oluşturulan araştırmanın çalışma grubunu bir devlet hastanesinin Çocuk ve Ergen Psikiyatri Polikliniğinde takip edilen, DEHB tanılı çocukların araştırmaya gönüllü katılan anneleri oluşturmaktadır. 11 katılımcı ile yürütülen çalışmada araştırmacılar tarafından geliştirilen yarı yapılandırılmış görüşme formu kullanılmıştır. Veriler yarı yapılandırılmış görüşme tekniği kullanılarak toplanmış ve yüz yüze yapılan görüşmelerde yazılı olarak kayıt altına alınmıştır. Kasım-Aralık 2017 tarihlerinde toplanan veriler içerik analizi yoluyla değerlendirilmiş ve katılımcıların cevapları doğrultusunda kategoriler oluşturulmuştur. Araştırma sonucunda annelerin eğitim sürecinde çocuklarının ihtiyaç duyduğu desteği tek başına sağlamak zorunda kaldıkları, okul personelinden ve diğer aile bireylerinden yeterli desteği göremedikleri belirlenmiştir. Genel anlamda ülkemiz eğitim sisteminin çocuklarının bireysel özelliklerini gözardı ettiğinden dolayı, sorunların daha yoğun yaşandığını belirtmişlerdir. En çok destek

* Makalenin ilk hali "VIII. International Conference on Critical Education (25-28 Temmuz 2018, Londra)" kongresinde sunulmuştur.

** Kırklareli Üniversitesi, Sağlık Yüksekokulu, Çocuk Gelişimi Bölümü, E-posta: elifcandidin@gmail.com, Sorumlu yazar, Orcid ID: https://orcid.org/0000-0002-9364-2293

*** Ankara Üniversitesi, Sağlık Bilimleri Fakültesi, Çocuk Gelişimi Bölümü, E-posta: koksalaysel@gmail.com, Orcid ID: https://orcid.org/0000-0002-1500-2960 
almaları gerektiğine inandıkları okul rehberlik servislerince verilen desteğin yeterli ve tutarlı bir özellik göstermediğini ifade etmişlerdir.

Anahtar Kelimeler: DEHB, ebeveynler, eğitim süreci, zorluklar.

\begin{abstract}
In this study, it was aimed to determine the problems faced by children diagnosed with Attention Deficit/Hyperactivity Disorder at schools according to the views of mothers. Also the sub-aim of the study is also to examine the views of mothers with children diagnosed with ADHD on the difficulties experienced with their children at home. The study was designed in the qualitative model using the case design. The sample group of the study formed with snowball sampling, from the purposeful sampling methods, consisted of voluntary mothers of children who were followed up in the Child and Adolescent Psychiatry Outpatient Clinic of a public hospital and were diagnosed with Attention Deficit/ Hyperactivity Disorder. A semi-structured interview form developed by the researchers was used in the study conducted with 11 participants. The data were collected using semi-structured interview technique and the face-to-face interviews were recorded in written form. The data collected between November and December 2017 were evaluated with content analysis method and the categories were formed according to the responses of the participants. Mothers of the children diagnosed with Attention Deficit Hyperactivity Disorder indicated that educational problems were experienced more intensely because the system of education in Turkey generally ignored personal characteristics of children. They stated that the support provided by school guidance services from which they believed to need to receive the greatest support was not sufficient and consistent. As a result of the study, it was determined that various problems were experienced in the process of education, the mothers had to provide support to their children on their own and they were not supported by the school personnel and other family members adequately.
\end{abstract}

Keywords: Attention deficit/hyperactivity disorder, parent, process of education, difficulties.

\title{
Giriş
}

Ulusal Sağlık Örgütü (The National Institutes of Health) tarafından önemli bir halk sağlı̆̆ sorunu olarak ilan edilen Dikkat Eksikliği/Aşırı Hareketlilik Bozukluğu (DEHB) (Neihart, 2003), kişisel, akademik, aile ve sosyal işlevleri etkileyen nörogelişimsel bir bozukluktur (APA, 2013). DEHB, çocuk ve ergenlerde dünya genelinde tanılanan en yaygın klinik tablodur (Merikangas vd., 2011). Belirtilerin sıklıkla çocuklukta başlaması ve tedavinin okul dönemini kapsaması gibi nedenlerden dolayı daha çok çocukluk çağına özgü bir bozukluk olarak kabul görmüş olsa da yapılan araştırmalarda DEHB tanısı alan birçok çocukta belirtilerin erişkinlikte de devam ettiği görülmüştür (Faraone, Biederman ve Mick, 2006; Kessler vd., 2006).

DSM 5 (Amerikan Psikiyatri Birliği, Mental Bozuklukların Tanısal ve İstatistiksel Elkitabı 5 - Diagnostic and Statistical Manuel of Mental Disorders 5)'e göre DEHB tanısının konulabilmesi için 12 yaşından önce başlamış olan belirtilerin iki ve daha fazla ortamda gözleniyor olması gerekmektedir. Ayrıca DEHB dikkatsizliğin baskın olduğu görünüm, aşırı hareketliliğin/ dürtüselliğin baskın olduğu görünüm ve bileşik görünüm olmak üzere üç alt tip şeklinde görülebilmektedir (APA, 2013). 
DEHB belirtilerinde gelişimle birlikte değişimler görülür. Bebeklikte az ve düzensiz uyku, aşırı bağımlılık ve yeme problemleri söz konusu iken (Soykan-Aysev ve Erdoğan-Bakar, 2010), okulöncesi dönem çocuklarında aşırı hareketlilik en temel semptomdur (Schachar ve Tannock, 2002). Bu dönemde söz dinlememe, akranları ile iletişim ve oyun kurmada zorluk, amaca yönelik davranış azlığı da sık görülen belirtiler arasındadır (Soykan-Aysev ve Erdoğan-Bakar, 2010). Okul çağında dikkat bozukluğu öne çıkmaya başlar. Ergenlik döneminde ise aşırı hareketlilik azalıp yok olurken, dikkat bozukluğu ve dürtüsellik en belirgin ve sıkıntı yaratan semptomlar haline gelir (Schachar ve Tannock, 2002). Bu dönemde zayıf sosyal ilişkiler, düşük benlik algısı, antisosyal davranışlar ve saldırganlık görülebilir (Soykan-Aysev ve Erdoğan-Bakar, 2010). Genel olarak bakıldığında çocuklarda görülen dikkatsizlik; akranlarına göre dikkatlerini toplama ve sürdürmede güçlük yaşamalarını, plansız ve düzensiz çalışmalarını, başkalarının fark etmediği ve önemsemediği uyaranlar nedeniyle işlerini yarıda kesmelerini, unutkanlık yaşamalarını, eşyalarını sıklıkla kaybetmelerini ifade ederken; hiperaktivite ise hareketlerini kontrol etmedeki yetersizliklerini, aynı anda birçok işi yürütmeye çalışmalarını, sürekli bir şeyle oynama, uğraşma ihtiyacı içinde olmalarını, ders çalışırken ya da yemek yerken sık sık bir bahane ile ayağa kalkmalarını ifade etmektedir. Sırasını bekleyememeleri, soru bitmeden cevap vermeleri, ani kararlar vermeleri, öfkelerini kontrol etmede yaşanılan güçlükleri de dürtüsellik boyutu olarak tanımlamaktadır (NIMH, 2018; Wassestein, 2005). DEHB'de görülen problemler yalnızca dikkat eksikliği, aşırı hareketlilik ve dürtüsellik ile sınırlı değildir. Engellenmeye ve baskıya dayanıksız olmaları nedeniyle özdenetim (Bahçivan-Saydam, Ayvaşık ve Alyanak, 2015) ve duygu düzenleme (Crundwell 2001; Deruelle, Da Fonseca, Poinso, Santos, Seguier, 2008; Reimherr vd., 2005) sorunları da sıklıkla görülebilmektedir. Yapılan araştırmalarda özellikle bileşik görünüm DEHB tanılı çocukların duygu düzenleme ve özdenetimde sorunlar yaşadıkları ve sonucunda olumsuz davranışlar gösterdikleri belirlenmiştir (Martel ve Nigg, 2006; Voeller, 2004). Ayrıca bu çocukların sosyal becerileri de zayıf olabilmektedir. Özdenetimleri ve duygusal düzenlemeleri zayıf olduğundan problemler karşısında ilk seçenek olarak şiddet eğilimi gösterebilmektedirler (Turgay, 2004). Yapılan araştırmalarda jest, mimik ve ses tonlamalarını tanımada güçlükler yaşadıkları ve var olan dürtüsellikten dolayı da duyguları tanımada zorlandıkları belirlenmiştir. Sosyal ipuçlarını anlamada sorun yaşayan DEHB'li çocuklar, sıklıkla uygun olmayan tepkiler verebilirler. Sürdürebildikleri arkadaşlıkları azdır ve aile ilişkilerinde de sıklıkla uyuşmazlık ve problemler yaşayabilirler (Biederman, Petty, Clarke, Lomedico ve Faraone, 2011; Deault, 2010; Johnston ve Mash, 2001).

Türk eğitim sisteminde DEHB tanılı çocukların çoğunluğu normal okullarda eğitimlerine devam ederken bir kısmı da özel eğitim ve ilgili hizmetlerden yararlanmaktadır. DEHB tanılı çocuklar okullarda kaynaştırma öğrencileri olarak Bireysel Eğitim Planı çerçevesinde ilgili Rehberlik Araştırma Merkezi’nin verdiği karar doğrultusunda özel eğitim kurumlarında veya özel eğitim alt sınıflarında da birebir eğitim almaktadırlar (MEB, 2017). Çocukla ilgili eğitim uygulamalarından hangisine karar verileceği çocuktaki DEHB'nin türüne, DEHB'ye eşlik eden başka rahatsızlıkların olup olmadığına ve çocuğun gelişimsel özelliklerine bakılarak uzmanlarca belirlenmektedir (MEB, 2016). DEHB'li çocuklar yaşamakta oldukları dikkat eksikliği, aşırı 
hareketlilik, dürtüsellik ve özdenetim ile duygu düzenleme problemleri nedeniyle eğitim sürecinde birçok sorunla karşılaşmaktadırlar. Düşük akademik performans gösterme, disiplin cezası alma, okuldan atılma ve sinıfta kalmanın (Barkley, 2006; Murphy, 2002) yanı sıra gösterdikleri olumsuz davranışlar akran ilişkilerini (Bagwell, Molina, Pelham ve Hoza, 2001; Çakaloz, Akay ve Günay, 2007; Gonzalez ve Sellers, 2002) ve öğretmen yaklaşımlarını (Temel, 2013; Toros; 2003) olumsuz etkileyebilmektedir. DEHB'li çocuklarda sıkıcı ve tekrarlayıcı durumlarda ve grup çalışmalarında dikkat dağınıklığı daha sık görülürken, yeni ve ilgi çekici konularda ve birebir çalışmalarda dikkat eksikliği ve odaklanma sorunları görülmeyebilir (Doğan, 2016). Lauth ve Naumann’n araştırmalarında da öğretmen yapılandırmasının daha az olduğu, düz anlatım tekniğinin kullanıldığı ve kendi kendine öğrenmenin gerçekleştirilmesinin beklendiği durumlarda DEHB’li öğrencilerin problem davranışlarında artış görüldüğü, eğlenceli ve öğrenciöğretmen arasında birebir iletişimin kurulduğu durumlarda ise problem davranışların azaldığı görülmüştür (Özmen, 2010). Bu bulgular öğretmenlerin DEHB hakkında bilgi sahibi olmalarının ve bu bilgiler ışı̆̆ında ders sürecini planlamalarının önemini ortaya kaymaktadır. Ancak konu ile ilgili yapılan çalışmalar öğretmenlerin DEHB hakkında yeterli bilgiye sahip olmadıklarını göstermektedir (Almacıoğlu, 2007; Anderson, Watt, Noble ve Shanley, 2012; Soroa, Gorostiaga ve Balluerka, 2016; Toros, 2003).

DEHB tanılı çocuğu olan anne-babalar ile yürütülen araştırmalar incelendiğinde ise, bu annebabaların fiziksel ceza uygulamaya daha eğilimli olduğunu ve çocuklarına karşı daha az sıcaklık ve ilgi gösterdiklerini gösteren araştırmalara rastlanmaktadır (Alizadeh, Applequist ve Coolidge, 2007; Ghanizadeh ve Shams, 2007; Kepley ve Ostrander, 2007). Ayrıca bu anne-babaların özgüvenlerinin daha düşük olduğunu (Alizadeh, Applequist ve Coolidge, 2007; Johnson ve Reader, 2002) ve daha fazla psikiyatrik belirtiler gösterdiklerini (Gökçen, Özatalay ve Fettahoğlu, 2011; Karaman, Durukan ve Kara, 2012; Shur Fen Gau, 2007) saptayan araştırmalar da vardır. Dolayısıyla DEHB’nin sadece çocuğu değil, aileyi de etkilediği görülmektedir. Ayrıca tedavi edilmemiş ve desteklenmemiş DEHB’nin uzun dönem sonuçlarını inceleyen araştırmalarda, akademik sorunlar, okulu bırakma, suça yönelme, alkol ve madde kullanımı, intihar, kendine ve çevreye zarar verici riskli davranışlar, diğer psikiyatrik rahatsızlıklar, işsizlik, başarısız kişilerarası ilişkiler, aile ilişkilerinde sorunlar, düşük benlik saygısı gibi olumsuzlukların olduğu görülmektedir (Charach, Yeung, Climans ve Lillie, 2011; Hodgkins vd., 2011; Klein vd., 2012). Dolayısıyla DEHB’nin sadece çocukluk çağına özgü olmadığı, etkisinin tüm yaşama kronik bir bozukluk olduğu (Dalbudak, 2016) göz önüne alındığında erken tanı, destek ve tedavinin önemi ortaya çıkmaktadır. Buradan hareketle yola çıkılan bu araştırmada DEHB tanılı çocukların desteklenmeye ihtiyaç duydukları alanlardan biri olan eğitim süreçlerinde, annelerinin görüşlerine göre okullarda karşılaştıkları sorunların belirlenmesi amaçlanmıştır. Ayrıca DEHB tanılı çocukları olan annelerin, çocukları ile evde yaşadıkları zorluklara ilişkin görüşlerinin incelenmesi de araştırmanın alt amacını oluşturmaktadır. 


\section{Yöntem}

DEHB tanılı çocukların eğitim süreçlerinde yaşadıkları zorluklarla ilgili örnekler ortaya koyabilmek, anlayışın ve deneyimlerin gelişmesine katkıda bulunabilmek, yapılabileceklerle ilgili daha etkili ve verimli kararlar verilmesine yardımcı olabilmek ve sürece ilişkin annelerin bakış açısını derinlemesine irdeleyebilmek amacıyla, bu araştırma nitel modelde tasarlanmış ve durum deseni kullanılmıştır. Bir duruma ait etkenlerin bütüncül bir yaklaşımla araştırıldığı ve ilgili durum ile karşılıklı etkileşimlerine bakıldı̆̆ incelenir (Merriam, 2015; Yıldırım ve Şimşek, 2016). Bu araştırmada ele alınan durum annelerin görüşlerine göre DEHB tanılı çocuklarının okul süreçlerinde yaşadıkları zorluklar ve annelerin, çocukları ile evde yaşadıkları zorluklara ilişkin görüşleridir. Bu araştırmadaki süreç Şekil 1.de verilmiştir. Araştırmada amaçlı örnekleme yöntemlerinden kartopu örnekleme kullanılmıştır. Amaçlı örnekleme, konu hakkında zengin bilgiye sahip olduğu düşünülen durumların araştırılmasına olanak sağlamaktadır (Yıldırım ve Şimşek, 2016). Kartopu tekniği ile belirlenen ilk katılımcı yardımıyla aranılan özelliklere sahip diğer katılımcılara ulaşılır. Kartopu örnekleme ile çalışmada yer alan ölçütlere uyan katılımcılara kolayca yer verilir (Merriam, 2015). Bu çalışmada ölçüt annelerin DEHB tanılı çocuklarının olmasıdır.

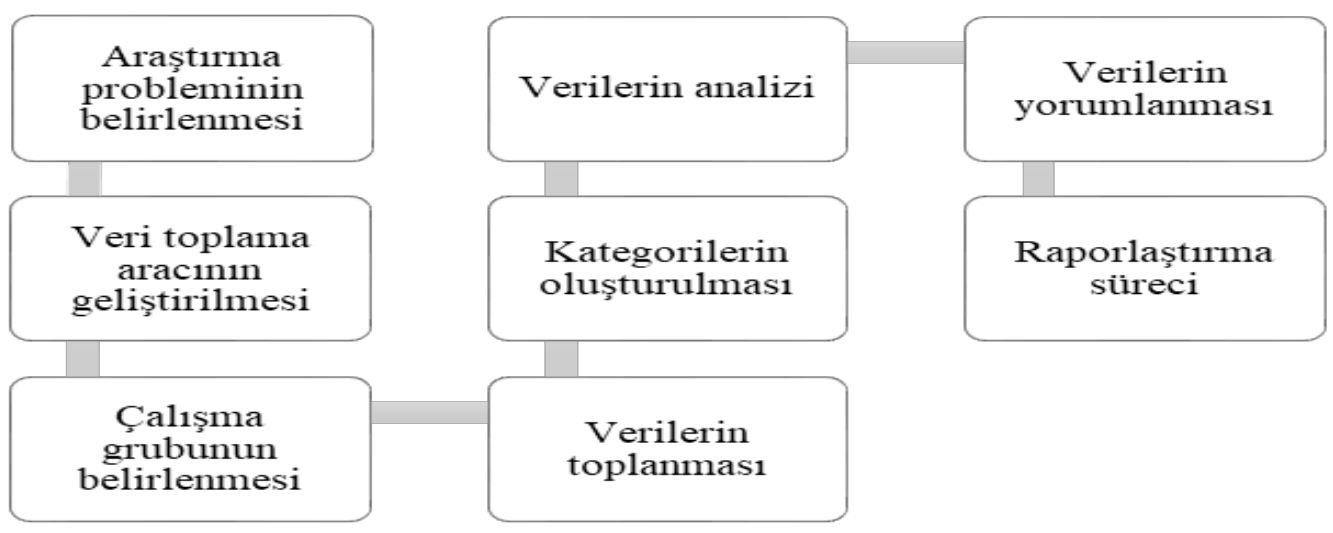

Şekil 1. Veri analiz sürecini gösteren akış planı

\section{Çalışma grubu}

Araştırmanın çalışma grubunu, Isparta ilindeki devlet hastanelerinde Çocuk ve Ergen Psikiyatri Polikliniği’nde takip edilen, tanılanma yılına göre Mental Bozuklukların Tanısal ve Sayımsal El Kitabı - Dördüncü Baskı (DSM-IV-TR) veya Beşinci Baskı (DSM-V) tanı ölçütlerine göre DEHB tanısı konulan, araştırmaya gönüllü katılan çocukların anneleri oluşturmuştur. Doğası gereği, nitel araştırmalarda genelleme yapmak uygun değildir, ancak nakledilebilirliğin sağlanması önemlidir. Bunun anlamı, araştırma bulgularının başka yerde, başka kişilerce yararlanılabilir olmasıdır. Yani okuyucular ve diğer araştırmacılar, kendi durumlarıyla, araştırılan durumun ne derece örtüştüğünü görebilmelidirler. Bunun için de araştırmacının nitel 
araştırmalarda, örneklem seçiminde çeşitliliği sağlaması önemlidir (Merriam, 2015). Bu nedenle araştırmanın çalışma grubunu oluşturan 11 katılımcının kendilerinin ve de çocuklarının yaş, öğrenim durumu ve tanılanma süreçleri gibi değişkenlerinde mümkün olduğunca çeşitlilik sağlanmaya çalışılmıştır. Çalışmaya katılan gruba ait özellikler Tablo 1.de verilmiştir.

\section{Tablo 1}

\section{Çalıșma Grubunun Özellikleri}

\begin{tabular}{|c|c|c|c|}
\hline \multicolumn{2}{|r|}{ Annenin } & $\mathrm{N}$ & $\%$ \\
\hline \multirow{4}{*}{ Yaşı } & $31-35$ & 4 & 36,36 \\
\hline & $36-39$ & 3 & 27,28 \\
\hline & $41-49$ & 4 & 36,36 \\
\hline & Toplam & 11 & 100 \\
\hline \multirow{4}{*}{ Öğrenim Durumu } & İlkokul & 4 & 36,36 \\
\hline & Lise & 3 & 27,28 \\
\hline & Lisans & 4 & 36,36 \\
\hline & Toplam & 11 & 100 \\
\hline \multirow{3}{*}{ Çocuğunun Cinsiyeti } & $\mathrm{K} 1 \mathrm{z}$ & 2 & 18,18 \\
\hline & Erkek & 9 & 81,82 \\
\hline & Toplam & 11 & 100 \\
\hline \multirow{4}{*}{ Çocuğunun Yaşı } & $8-9$ & 4 & 36,36 \\
\hline & $10-13$ & 3 & 27,28 \\
\hline & $14-17$ & 4 & 36,36 \\
\hline & Toplam & 11 & 100 \\
\hline \multirow{4}{*}{$\begin{array}{c}\text { Çocuğunun Öğrenim } \\
\text { Durumu }\end{array}$} & İlkokul 2-4.Sınıf & 5 & 45,46 \\
\hline & İlkokul 5-6. Sinıf & 2 & 18,18 \\
\hline & Lise 1-4. Sinıf & 4 & 36,36 \\
\hline & Toplam & 11 & 100 \\
\hline \multirow{4}{*}{$\begin{array}{c}\text { Çocuğunun Tanılanma } \\
\text { Zamanı }\end{array}$} & 6 ay-1 Yil önce & 4 & 36,36 \\
\hline & 2-4 Yll önce & 3 & 27,28 \\
\hline & 5-9 Yll önce & 4 & 36,36 \\
\hline & Toplam & 11 & 100 \\
\hline \multirow{4}{*}{ Çocuğunun Tanısı } & Dikkatsizliğin baskın olduğu görünüm & 4 & 36,36 \\
\hline & Aşırı hareketliliğin/dürtüselliğin baskın olduğu görünüm & 2 & 18,18 \\
\hline & Bileşik görünüm & 5 & 45,46 \\
\hline & Toplam & 11 & 100 \\
\hline
\end{tabular}

\section{Veri toplama araçarı}

Çalışmada uzman görüşleri alınarak araştırmacılar tarafından geliştirilen yarı yapılandırılmış görüşme formu kullanılmıştır. Formda, katılımcıların demografik özelliklerini; çocuklarının okul ortamları, okulda yaşanılan zorluklar ve evde yaşadıkları zorluklara ilişkin görüşlerini belirlemek için hazırlanmış toplam yedi temel soru ve bunlara bağlı sonda sorulara yer verilmiştir. Temel soruları takiben sorulan sonda sorular ile katılımcıların amaçtan sapması önlenmekte; 
elde edilebilecek daha fazla veri olup olmadığını görülmektedir (Merriam, 2015). Araştırmada sorulan sorular aşağıda verilmiştir.

1.Kendinizden ve ailenizden bahseder misiniz? (Yaş/ Eğitim durumu/Meslek vb.)

2.Bana biraz çocuğunuzdan bahseder misiniz? (Yaşı/ Cinsiyet/ Eğitim durumu/ Tanı konma zamanı vb.)

3.Çocuğunuzun okul ortamından bahseder misiniz? (Arkadaş İlişkileri/ Öğretmen bakış açıları/ Diğer ailelerin bakış açıları/ Ders durumları vb.)

4. Çocuğunuz ile ilgili yaşanılan zorluklardan bahseder misiniz?

4a.Çocuğunuzun okulda zorlandığını düşündüğünüz şeyler nelerdir?

4b.Çocŭ̆unuzun eğitim sürecinde sizin zorlandı̆̆ınız şeyler nelerdir?

4c.Çocuğunuzla birlikte ev yaşantısında yaşanılan zorluklar nelerdir?

4d. Bu zorlukları karşısında kendinizi nasıl hissediyorsunuz?

5.Yaşanılan bu zorlukların çözümünde sizlere destek olan kişilerden ve yardımlarından biraz bahseder misiniz? (Yönetim/ Eğitimci/ Çocuğunuzun arkadaşlarl/ Diğer aileler /Sizin arkadaşlarınız /Akrabalar vb.)

6.Sizce çocuğunuzun ve sizin okulda sorun yaşamaması için neler yapılabilir?

7.Çocuğunuzun eğitim yaşamı sürecinde yaşadığınız sizi etkileyen olumlu ve olumsuz önemli birer olayı bizimle paylaşır mısınız?

\section{Veri toplama ve analizi}

Veriler yarı yapılandırılmış görüşme tekniği kullanılarak toplanmıştır. Yarı yapılandırılmış görüşmede katılımcının algıladığı dünyayı kendi düşünceleriyle anlatması hedeflenmektedir (Merriam, 2015). Görüşme sırasındaki eksikliklerin, anlaşılmazlıkların ortaya çıkarılması için iki anne ile pilot çalışma yapılmıştır. Yüz yüze yapılan görüşmelerde veriler yazılı olarak kayıt altına alınmıştır. Verilerin tümü Kasım-Aralık 2017 tarihleri arasında toplanmıştır. Veriler içerik analizi yoluyla değerlendirilmiş ve katılımcıların cevapları doğrultusunda kategoriler oluşturulmuştur. Bir veri analizi olan kategori oluşturmada kategoriler, araştırma sorularına cevap verebilir nitelikte olmalıdır (Merrriam, 2015). Araştırmanın geçerliğini arttırmak amacıyla katılımcıların cevaplarından doğrudan alıntılara yer verilmiş ve katılımcı isimleri A1, A2..., A11 şeklinde kodlanmıştır. Bu uygulama dış geçerlilik/nakledilebilirliği sağlamaya yardımcı olmakta ve anneler tarafından verilen yanıtlara ilişkin kanıtlarla desteklenen bulguların detaylı olarak tanılanmasına hizmet etmektedir (Merriam, 2015). Veri analizinin güvenirliği Miles ve Huberman (2015)'ın [Görüş birliği/ (Görüş birliği + Görüş ayrılığı) X 100] formülü kullanılarak hesaplanmıştır. Buna göre iki araştırmacı tüm sorulara ait tabloları birlikte oluşturmuş ve \% 100 güvenirlik sağlanmıştır. Araştırmacı üçgenlemesi olarak açıklanan bu uygulama, ortaya çıkan 
bulguların doğruluk ve gerçekliğinin kontrolünü sağlamak için birden fazla araştırmacının değerlendirme yapması olarak ifade edilmektedir (Merriam, 2015).

\section{Bulgular}

Annelerinin görüşlerine göre DEHB tanılı çocukların okullarda karşılaştıkları sorunların, ayrıca çocukları ile evde yaşadıkları problemlerin incelendiği bu araştırmada elde edilen bulgular aşağıda özetlenerek tablolar halinde sunulmuştur.

Tablo 2

Dikkat Eksikliği/Aşırı Hareketlilik Bozukluğu (DEHB) Tanılı Çocukların Annelerine Göre Eğitim Sürecinde Yaşadıkları Zorluklar

\begin{tabular}{|c|c|c|c|c|c|c|c|c|c|c|}
\hline & A1 $A 2$ & A3 & A4 & A5 & A6 & A7 & A8 & A9 & A10 & A11 \\
\hline \multicolumn{11}{|l|}{ Akran İlişkileri } \\
\hline \multicolumn{11}{|l|}{ Pek arkadaşı yok } \\
\hline \multicolumn{11}{|l|}{ Sıklıkla sorun yaşama } \\
\hline \multicolumn{11}{|l|}{ Ara sıra sorun yaşama } \\
\hline \multicolumn{11}{|l|}{ Öğretmen İlişkileri } \\
\hline \multicolumn{11}{|l|}{ Sıklıkla çatışma } \\
\hline \multicolumn{11}{|l|}{ Olumlu iletişim } \\
\hline \multicolumn{11}{|l|}{ Okul Başarısı } \\
\hline \multicolumn{11}{|l|}{ Düşük } \\
\hline \multicolumn{11}{|l|}{ Orta derece } \\
\hline \multicolumn{11}{|l|}{ Yüksek } \\
\hline \multicolumn{11}{|l|}{ Eğitim Sürecinde Yaşanılan Zorluklar } \\
\hline \multicolumn{11}{|l|}{ Sürekli ders/ödev desteği ihtiyacı } \\
\hline \multicolumn{11}{|l|}{ Öğretmen/yönetim tarafından anlaşılmama } \\
\hline \multicolumn{11}{|l|}{ Uyum göstermede zorlanma } \\
\hline \multicolumn{11}{|l|}{ İnat etme } \\
\hline \multicolumn{11}{|l|}{ Sözel ve durağan derslerde zorlanma } \\
\hline \multicolumn{11}{|l|}{ Eşyaları hor kullanma/kaybetme } \\
\hline \multicolumn{11}{|l|}{ Yerinde duramama } \\
\hline \multicolumn{11}{|l|}{ İlginin çabuk dağılması } \\
\hline Saldırgan/kavgacı tutumlar & & & & & & & & & & \\
\hline Disiplin cezası, okuldan kaçma, sınıfta kalma vb. & & & & & & & & & & \\
\hline
\end{tabular}

Tablo 2 incelendiğinde annelerin DEHB tanılı çocuklarının akran ilişkilerinde çeşitli derecelerde problemler yaşadıklarını, öğretmenleri ile sıklıkla çatışma içerisinde olduklarını, genel olarak orta derecede ders başarısı gösterdiklerini belirttikleri görülmektedir. A5 bu durumu anlatırken "İlgisini çekmeyen konularla arkadaşları ile sorunlar yaşar. Genellikle bireysel takılır, gruplara pek girmez. Pek arkadaşı yok. Öğretmenleri genel anlamda bilinçli. Aslına bakarsanız yeni nesil ögrretmenler bu konuda daha bilinçli. Arkadaşça yaklaşıp sorunları çözmeye çalışıyorlar. Eski 
tarz öğretmenler otorite kurmaya çalş̧tı̆̆ için ve kızım da inatçı olduğu için sıklıkla anlaşmazlık çıkıyor." ifadelerini kullanırken, A8 "Ders başarısı düşük ama öğretmenler ile arası genel olarak iyidir. Okula başlarken tanı konulduğu için öğretmeni zaten biliyor. Arkadaşlarılla da arası iyi sayılır ama daha çok derse ilgisi olmayan arkadaşlar ile takılır." demiştir. A11 ise "Sevecen bir çocuk olmasına rağmen düzenli ve uzun süreli arkadaşlklar kuramiyor. Umursamaz davranıor. Çabuk kaynaşıyor ama çabuk sıkılıyor. Derste de çabuk sıkıllyor. İşin kolayına kaçar genelde. Bazı konuları gereksiz görüyor ya da ödevleri unutuyor. Yine de öğretmenleri ile arası iyi sayıllr." şeklide açıklama yapmıştır.

Ayrıca tablo incelendiğinde, annelerin çocuklarının sürekli ders çalışma ve ödev yapma sürecinde desteğe ihtiyaç duyduklarını, sözel ve durağan derslerde zorlandıklarını, ders sürecinde sınıf içerisinde sabit durma ve derse ilgi göstermede problemler yaşadıklarını ifade ettikleri belirlenmiştir. A1 bu durumu "Okuması biraz yavaştır. Sözel derslerde zorlanıyor. Sürekli destek olmak zorunda kaliyorum. Tek başına ödev yapmiyor. Okulda dikkatini toplayamayı başka şeylerle uğraşmaya başlayınca sık sık yerini değiştiriyormuş öğretmeni." şekilde açılarken, A4 "Çok dağınıktır, zaman zaman çevreye uyum sorunları yaşıyor. Öfke atakları, agresif davranışları oluyor. Sigara kullanıyor, ara ara alkol aldı̆̆ı da olmuş. Okula geç kalır, umursamaz, bu yüzden devamsızlık sorunu yaşıyor. Agresif davranışları eşyalara karşı da oluyor. Eşyaları kırar ya da bozar. Başına buyruk davranır, bazen telefonlarına da cevap vermez." ifadelerini kullanmıştır. A7 "Aslında hem dikkatinin dağınık olmasından hem de hiperaktif olmasından dolayı yanlı̧̧ anlaşılmalar yaşanıyor. Bir de çok inatlaşıyor, hem bizimle hem okuldakilerle." ve A9 ise "Çabuk sıkılır, yerinde duramaz. Organize değil, işleri dağınık yapar. Sürekli ilgilenmek, arkasını toplamak, başında durmak, uyarmak zorundayım." demiştir.

\section{Tablo 3}

Dikkat Eksikliği/Aşırı Hareketlilik Bozukluğu (DEHB) Tanılı Çocukları Olan Annelerin Çocuklarının Eğitim Sürecinde Yaşadıkları Zorluklara İlişkin Görüşleri

\begin{tabular}{|c|c|c|c|c|c|c|c|c|c|c|c|}
\hline & A1 & $A 2$ & A3 & $A 4$ & A5 & A6 & A7 & A8 & A9 & $A 10$ & A11 \\
\hline \multicolumn{12}{|l|}{ Süreçte Destek Gösterenler } \\
\hline \multicolumn{12}{|l|}{ Hiç kimse } \\
\hline \multicolumn{12}{|l|}{ Sosyal çevre, akrabalar } \\
\hline \multicolumn{12}{|l|}{ Diğer veliler } \\
\hline \multicolumn{12}{|l|}{ Öğretmen } \\
\hline \multicolumn{12}{|l|}{ Yönetim } \\
\hline \multicolumn{12}{|l|}{ Annenin Duygulari/Durumu } \\
\hline \multicolumn{12}{|l|}{ Yoğun/Bir koşturmaca içerisinde } \\
\hline \multicolumn{12}{|l|}{ Yorgun/yetersiz } \\
\hline \multicolumn{12}{|l|}{ Yalnız } \\
\hline \multicolumn{12}{|l|}{ Annenin Beklentileri } \\
\hline Rehberlik servisinden destek & & & & & & & & & & & \\
\hline Öğretmenlerin bilinçlendirilmesi & & & & & & & & & & & \\
\hline
\end{tabular}


Diğer velilerin bilinçlendirilmesi Ailenin bilgilendirilmesi

Sınıfi/ders işlenişini çocuğun ihtiyacına göre düzenleme Destek eğitim hizmetleri
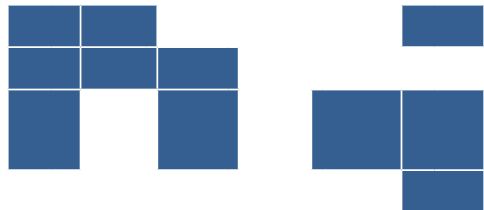

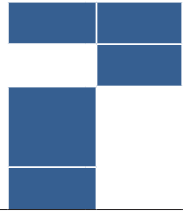

Tablo 3 incelendiğinde DEHB tanılı çocukları olan annelerin çocuklarının eğitim sürecinde yaşadıkları zorluklarda genellikle yalnız olduklarını, kimseden destek görmediklerini belirttikleri görülmektedir. Bazı aileler bu süreçte öğretmenlerden destek aldıklarını ifade etmiştir. Ayrıca tablo incelendiğinde sosyal çevre, akraba, diğer veliler ve yönetimin destek mekanizması olarak etkin olmadıkları görülmektedir. A5 bu durumu "İlköğretimdeyken öğretmeni yönlendirdi hastaneye, bu yüzden şanslıyız diyebilirim. Şu anki müdürüyle pek anlaşamıyoruz. Çocuğu sürekli sorun çıkaran biri olarak görüyor. Akrabalarımız da genellikle çok karışıyor. İlaç kullanmasını istemiyorlar, beynini, karaciğerini etkiler kalıcı hasar bırakır diyorlar.” şeklinde ifade ederken A6 "Ne okuldan ne çevreden kimseden yardım görmedik. Birde yaramaz diye sevmediler üstelik." demiştir. A7 "Okulda sadece öğretmeni bize yardımcı oldu. Onun dışında ne yöneticilerden, ne akrabalardan ne de diğer ailelerden en ufak bir yardım görmedik." ve A10 ise "Kimseden yardım almadık, kimse bu hastalığı bilmiyor zaten.” şeklinde açıklamalarda bulunmuşlardır.

Anneler kendilerini çoğunlukla yalnız hissettiklerini ve sürekli bir koşturmacanın içerisinde olduklarını belirtmişlerdir. A4 "Hep desteğe ihtiyacı var gibi. Tek başıma bir yere kadar yetebiliyorum. Yoruluyorum, yardıma ihtiyacımız var." derken, A6 “Sürekli hareket halinde, motor takılmış gibi, bizi çok yoruyor.”, A8 "Sürekli destek olmak ve başında durmak zorunda kalıyorum ve gerçekten çok zorlanıyorum. Bazen tek başıma yetersiz kalabiliyorum ya da yoruluyorum." ve A11 ise "Sürekli arkasını toparlamak zorundayım. Ben de öğretmen olduğum için yakından ilgilenmeye çalışıyorum. Öğretmenleri ile sürekli iletişimde kalmaya çalışıyorum.” demiştir.

Araştırmaya katılan, DEHB tanılı çocukları olan anneler, çocuklarının eğitim sürecinde yaşadıkları sorunlarla baş edebilmeleri adına çoğunlukla rehberlik servisinden destek beklediklerini, başta öğretmenler olmak üzere diğer velilerin de bu konu hakkında bilinçlendirilmesi gerektiğini ve sınıfın/ders işlenişinin çocuğun ihtiyacına göre düzenlenmesi gerektiğini ifade etmişlerdir. A3 düşüncelerini “Okul yönetimi ve öğretmenler genel olarak farkında değil bu hastalığın. Daha çok zeka problemi zannediyorlar. Önce öğretmenler bilinçlendirilmeli, bu konuda eğitim almalılar. Çocuk arka sıraya oturtulmamal, ön stralarda dikkatini çekecek şekilde ders anlatılmalı. Ailelere de eğitim verilmeli. Biz çok erken fark ettiğimiz için hem biz hem de akrabalar bilinçlendi ama hiç bilgisi olmayan aileler çok." ifadeleri ile açıllarken A5 "Okullarda araştırarak, deneyerek öğrenme üzerine etkinlikler yapılabilir. Ders programlarında çocukların bireysel merakları ve ilgileri pek dikkate alınmıyor. Bu yüzden ilgi ve merakları köreliyor. Ailelere bu yönde bilgilendirmelere yapılsa ve nasıl destek vereceğimiz öğretilse daha iyi olurdu. Biz kendi çabalarımızla öğrenmeye çalışıyoruz. Özellikle anasınıfında sürekli resim, müzik etkinlikleri oluyor ve çocuklar sürekli aynı şeylerden sikılıyorlar. Çocukların eğilimleri ve yetenekleri tespit edilip fiziksel aktivitelerini de tolere edebilecek, enerjilerini harcayabilecekleri aktiviteler planlanması lazım. Yapma, etme demek yerine şunu yapalım mi, şunu yapmak ister misin, ne yapmak istersin gibi bir 
yaklaşım olmalı." ve A6 "Öğretmenleri sürekli değişiyor. Bu değişiklikten çocuk da etkileniyor, uyum sağlayamıyor. Öğretmenler yanlış anlatıyor, yaramaz ve kavgacı diye etiketlemeseler ve gerçekten bu hastalı̆̆ın farkında olsalar ne iyi olurdu." Demiștir. A7 "Rehberlik öğretmenleri ile birebir ve düzenli bir görüşme olanağı olsa iyi olurdu. Ama bu görüşmelerin süreklilik arz etmesi lazım. Rehberlik öğretmenleri genellikle özel eğitim öğrencileriyle ilgileniyor okulda. Ama tüm çocukların desteğe ihtiyacı var, çünkü herkesin sorunu farklı. Okulda onlar için de düzenlemeler yapılmalı." derken A8 ise "Özel dersler, destek eğitimler olabilir. Tek başıma yetersiz kalabiliyorum çünkü. Birde rehberlik öğretmeni birebir ilgilense daha iyi olurdu. Diğer ailelerde bilgilendirilmeli aslinda. Bu tarz çocuklar göz ardı ediliyor." diyerek düşüncelerini belirtmiştir.

\section{Tablo 4}

Dikkat Eksikliği/Aşırı Hareketlilik Bozukluğu (DEHB) Tanılı Çocukları Olan Annelerin Çocukları ile Evde Yaşadıkları Zorluklara İlişkin Görüşleri

\begin{tabular}{cccccccccc|c|c|c}
\hline & $A 1$ & $A 2$ & $A 3$ & $A 4$ & $A 5$ & $A 6$ & $A 7$ & $A 8$ & $A 9$ & $A 10$ & $A 11$ \\
\hline $\begin{array}{c}\text { Kardeş kavgaları } \\
\text { Aile bireyleri arasında çatışma } \\
\quad\end{array}$ & & & & & & & & & & & \\
$\quad \begin{array}{c}\text { Dağınıklı } \\
\text { Yerinde duramama } \\
\text { Eşyalara zarar verme }\end{array}$ & & & & & & & & & & & \\
\hline
\end{tabular}

Tablo 4 incelendiğinde araştırmaya katılan annelerin DEHB tanılı çocuklarıyla evde yaşadıkları zorluklara ilişkin sıklıkla kardeş kavgaları yaşandığını, ev içerisinde çocuklarının çok hareketli olduklarını ve çocuklarının neden olduğu dağınıklı̆̆ı rapor ettikleri görülmektedir. A1 bu durumu "Eşyaların paylaşmaz kardeşiyle bu nedenle kavga ederler. Bir de çok dağınık olduğundan ve acele ettiğinden sorunlar yaşıyoruz. Hatalar yapıyor, eşyalarını kaybediyor." şeklinde açıklarken A2 "Evde hareketli bir yapısı var. Top oynar, sürekli bir yerleri karıştırır. Bu yüzden evde cam eşyalar kırılır sürekli. Çok inatçı olduğundan kardeşleriyle de, bizle de kavga eder.", A8 "Kendine zorla şarjlı matkap aldirdı. Bir ay boyunca oynad, her yeri deldi sonra söküp bozdu. Zaten her aleti hemen açıp bakar, çoğu zaman da bozar. Abisiyle araları iyi sayıllı. Aslinda abisi idare ettiği için öyle, yoksa kavga çıkarmaya yer arıyormuş gibi aslında." ve A10 ise "Kardeşi 4 yaşında, sürekli tartışıyor onunla. Biraz kıskanıyor o nedenle kavga çıkıyor. Sürekli hareket halinde ve evi dağıtıyor. Örümcek adam gibi. Perdeleri, banyo kornişlerini döne döne hep indirdi. Ödevleri ayakta yapıyor, bir de ödevi yapmak yerine kitaptaki şekilleri boyuyor sürekli." ifadeleriyle açıklamıştır.

\section{Tartışma ve Sonuç}

DEHB tanılı çocukların desteklenmeye ihtiyaç duydukları alanlardan biri olan eğitim süreçlerinde, annelerinin görüşlerine göre okullarda karşlaştıkları sorunların belirlenmesi ve DEHB tanılı çocukları olan annelerin, çocukları ile evde yaşadıkları zorluklara ilişkin görüşlerinin incelenmesi amacıyla yapılan bu araştırmada; katılımcı annelerin DEHB tanılı çocuklarının akran ilişkilerinde çeşitli derecelerde problemler yaşadıklarını, öğretmenleri ile 
sıklıkla çatışma içerisinde olduklarını belirttikleri görülmüştür. Ayrıca çocuklarının genel olarak orta derecede ders başarısı gösterdiklerini, sözel ve durağan derslerde zorlandıklarını, ders sürecinde sınıf içerisinde sabit durma ve derse ilgi göstermede problemler yaşadıklarını ifade ettikleri belirlenmiştir. Araştırmanın bir diğer önemli bulgusu ise sıklıkla kardeş kavgalarının ve aile bireyleri arasında çatışmaların yaşandığının rapor edilmiş olmasıdır. Bu bulgular DEHB'li çocukların sürdürebildikleri arkadaşlıklarının az olduğu ve aile ilişkilerinde sıklıkla uyuşmazlık ve problemler yaşadıklarını söyleyen (Biederman vd., 2011; Deault, 2010; Johnston ve Mash, 2001), gösterdikleri olumsuz davranışların akran ilişkilerini (Bagwell vd., 2001; Çakaloz vd., 2007; Gonzalez ve Sellers, 2002) ve öğretmenlerin yaklaşımını (Temel, 2013; Toros; 2003) olumsuz etkilediğini belirten ve ayrıca bu çocukların düşük akademik performans gösterdiklerini (Barkley, 2006; Murphy, 2002) belirleyen araştırmaların sonuçları ile tutarlılık göstermektedir. Annelerin DEHB tanılı çocuklarının en çok sözel ve durağan derslerde zorlandığını belirtmeleri; Lauth ve Naumann’n araştırmalarında belirlenen öğretmen yapılandırmasının daha az olduğu, düz anlatım tekniklerinin kullanıldığı ve kendi kendine öğrenmenin gerçekleşmesinin beklendiği durumlarda DEHB'li öğrencilerin problem davranışlarında artış görüldügünü, eğlenceli ve öğrenci-öğretmen arasında birebir iletişimin kurulduğu durumlarda ise problem davranışların azaldığını (Özmen, 2010) gösteren bulgularla paralellik göstermektedir.

Araştırmaya katılan anneler DEHB tanılı çocuklarının eğitim sürecinde yaşadıkları zorluklar karşısında genellikle yalnız olduklarını, kimseden destek göremediklerini belirtmişlerdir. Bazı aileler bu süreçte öğretmenlerden destek aldıklarını ifade etselerde öğretmen desteğinin her zaman görülmediği ve genel anlamda da sosyal çevre, akraba, diğer veliler ve yönetimin de destek mekanizması olarak etkin olmadıkları belirlenmiştir. Anneler kendilerini çoğunlukla yalnız hissettiklerini ve sürekli bir koşturmacanın içerisinde olduklarını belirtmişlerdir. Çocuklarında DEHB tanısı olan ebeveynlerin duygu durumlarının incelendiği araştırmalarda anne-babaların daha fazla psikiyatrik belirti gösterdikleri (Shur Fen Gau, 2007) görülmektedir ki bu durum araştırmaya katılan annelerin ifadeleri ile örtüşmektedir.

Katılımcılar çocuklarının eğitim sürecinde yaşadıkları sorunlarla baş edebilmeleri adına çoğunlukla rehberlik servisinden destek beklediklerini, başta öğretmenler olmak üzere diğer velilerin de bu konu hakkında bilinçlendirilmesi ve sınıfın/ders işlenişinin çocuğun ihtiyacına göre düzenlenmesi gerektiğini ifade etmişlerdir. Literatür incelendiğinde öğretmenlerin DEHB hakkında yeterli bilgiye sahip olmadıkları (Almacıoğlu, 2007; Anderson vd., 2012; Soroa vd., 2016; Toros, 2003) ve rehberlik servislerinde görevli psikolojik danışman ve rehber öğretmenlerinin de DEHB hakkında orta düzeyde bilgiye sahip oldukları (Almacıoğlu, 2007) görülmektedir. Ayrıca Sucuoğlu ve Akalın (2010), yapmış oldukları araştrmalarında öğretmenlerin sınıflarındaki kaynaştırma öğrencilerinin başarılarını arttıracak yöntem ve teknikleri bilmediklerini, sınıf ortamında gerekli uyarlamaları yapamadıklarını ve bu nedenle özel gereksinimli çocukların gereksinimlerini genel eğitim sınıfında karşılayamadıklarını belirlemişlerdir. Bu bulgularla, araştırmaya katılan annelerin ifadeleri paralellik göstermektedir.

DEHB tanılı çocukların özelliklerini ve yaşadıkları zorlukları bilmek, onlara ne şekilde yaklaşılacağı ve nasıl destek olunacağı konusunda öğretmenlere ve ailelere yol gösterecektir. 
Yapılan araştırmalarda ilaç dışı tedaviler arasında ebeveyn eğitimi ve okula yönelik yapılan girişimlerin etkin olduğu belirtilmektedir (Ercan ve Aydın, 2011). O halde, öğretmenlerin DEHB'yi çok boyutlu bir şekilde ele alabilecek ve destekleyecek donanıma sahip olmaları ve hem aileyi hem de çocuğu doğru yönlendirebilmeleri oldukça önemlidir. Bu bağlamda sınıf, branş ve rehber öğretmen adaylarının eğitim programlarında DEHB gibi özel gereksinimleri olan, eğitim süreçlerinde farklı yaklaşımlar gerektiren bozukluklar üzerinde durulmalı, öğretmenler bu çocukları sınıf ortamında etkili bir biçimde yönlendirme, derse dahil etme, okulda alınabilecek önlemler, sınıf içi düzenlemeler, problemli davranışlarla baş edebilme, davranışları yönlendirme ve ebeveynlerle işbirliği gibi konularda desteklenmelidirler. $\mathrm{Bu}$ konularda verilen seminer ve hizmetiçi eğitimlerin sayısı arttırılabilir ve içeriği genişletilebilir. Ayrıca eğitimcilerin bu kapsamda hazırlanan kaynaklara ulaşımı kolaylaştırılabilir ve desteklenebilir. Öğretmenlere ve ailelere bu süreçlerde ihtiyaç duydukları desteğin sağlanması için, bu konularda eğitim alan çocuk gelişimcilerden ve özel gereksinimli çocuklar konusunda uzmanlaşmış özel eğitimcilerden destek alınabilir.

Psikolojik danışman ve rehber öğretmenlerinin, sınıf ve branş öğretmenlerinin, yönetimin ve ailenin iş birliği içerisinde olması eğitim sürecinin optimal düzeyde verimli olması açısından önemlidir. Bu işbirliği sayesinde DEHB'li çocuğun hem gelişimi hem de akademik başarısı desteklenecek, ailenin ve çocuğun duygu-durumu olumlu yönde değişecek ve bozukluğun morbiditesinde azalma meydana gelebilecektir.

Bu araştırmanın bulguları, Yıldırım ve Şimşek (2016)'in de belirttiği gibi, nitel araştırmaların doğası gereği özneldir ve genelleme yapmaya uygun değildir Ancak bu bulgular ile okuyuculara ve diğer araştırmacılara, DEHB tanılı çocukların eğitim süreçlerinde yaşadıkları zorluklarla ilgili örnekler gösterebilmek, anlayışın ve deneyimlerin gelişmesine katkıda bulunabilmek, yapılabileceklerle ilgili daha etkili ve verimli kararlar verilmesine yardımcı olabilmek ve sürece ilişkin annelerin bakış açısını derinlemesine irdeleyerek, fikir sunmak hedeflenmiştir. Daha kapsamlı bilgiler elde edebilmek için, bu araştırmanın bulgularından yola çıkılarak farklı araştırma yöntemleri ile konu daha büyük ve farklı örneklem grupları ile çok yönlü bir şekilde incelenebilir, analiz edilebilir ve değerlendirilebilir. Ayrıca bu süreçte katılımcıların sundukları önerilerinden de yararlanılabilir.

\section{Kaynaklar}

Alizadeh, H., Applequist, K. F., \& Coolidge, F. L. (2007). Parental self-confidence, parenting styles, and corporal punishment in families of ADHD children in Iran. Child Abuse \& Neglect, 31(5), 567-572.

Almacıoğlu, D. (2007). Yönetsel bir sorun olarak dikkat eksikliği ve hiperaktivite bozukluğu olan öğrencilerin sinıfve psikolojik damışma ve rehberlik öğretmenleri tarafından tanınma yeterliliklerinin incelenmesi. (Yüksek lisans tezi, Gaziantep Üniversitesi, Sosyal Bilimler Enstitüsü, Gaziantep, Turkey). http:// tez.yok.gov.tr/UlusalTezMerkezi Sayfasından erişilmiştir. (Tez Numarası: 226719)

Amerikan Psikiyatri Birliği (APA) (2013). Ruhsal bozuklukların tanısal ve sayımsal kitabı: Beşinci baskı tanı ölçütleri kitabı (DSM-5) (Çev. Ed. E. Köroğlu). Ankara: Hekimler Yayın Birliği. 
Anderson, D. L., Watt, S. E., Noble, W., \& Shanley, D. C. (2012). Knowledge of attention deficit hyperactivity disorder (ADHD) and attitudes toward teaching children with ADHD: The role of teaching experience. Psychology in the Schools, 49(6), 511-525.

Bagwell, C. L., Molina, B. S., Pelham, W. E., \& Hoza, B. (2001). Attention-deficit hyperactivity disorder and problems in peer relations: Predictions from childhood to adolescence. Journal of the American Academy of Child \& Adolescent Psychiatry, 40(11), 1285-1292.

Bahçivan Saydam, R., Ayvaşık, H. B., \& Alyanak, B. (2015). Executive functioning in subtypes of attention deficit hyperactivity disorder. Archives of Neuropsychiatry, 52(4), 386-392.

Barkley, R. A., Fischer, M., Smallish, L., \& Fletcher, K. (2006). Young adult outcome of hyperactive children: adaptive functioning in major life activities. Journal of the American Academy of Child \& Adolescent Psychiatry, 45(2), 192-202.

Biederman, J., Petty, C. R., Clarke, A., Lomedico, A., \& Faraone, S. V. (2011). Predictors of persistent ADHD: an 11-year follow-up study. Journal of Psychiatric Research, 45(2), 150-155.

Charach, A., Yeung, E., Climans, T., \& Lillie, E. (2011). Childhood attention-deficit/hyperactivity disorder and future substance use disorders: comparative meta-analyses. Journal of the American Academy of Child \& Adolescent Psychiatry, 50(1), 9-21.

Crundwell, R.M.A. (2001). The relations of regulation and emotionality in children with attention deficit hyperactivity disorder: An initial investigation of barkley's theoretical model of ADHD. Doktora Tezi, Wayne State Üniversitesi. https://search.proquest.com/docview/304726470 Sayfasindan erişilmitir. (Tez Numarası: AAI3037065)

Çakaloz, B., Akay, A. P., \& Günay, T. (2007). Karşı olma karşı gelme bozukluğunun eşlik ettiği ve etmediği dikkat eksikliği ve hiperaktivite bozukluğu tanılı çocukların davranışsal sorunlar, ders başarısı ve akran ilişkileri açısından değerlendirilmesi. New/Yeni Symposium Journal, 45(2), 84-92.

Dalbudak, E. (2016). Dikkat eksikliği hiperaktivite bozukluğu, davranışsal bağımlılıklar ve erişkin yaşama yansımaları. Psikiyatride Güncel, 6(4), 324-334.

Deault, L. C. (2010). A systematic review of parenting in relation to the development of comorbidities and functional impairments in children with attention-deficit/hyperactivity disorder (ADHD). Child Psychiatry \& Human Development, 41(2), 168-192.

Deruelle, C., Da Fonseca, D., Poinso, F., Santos, A. \& Seguier, V. (2008). Emotion understanding in ADHD children. Child Psychiatry and Human Development, 40(1), 111-21.

Doğan, S. (2016). Erişkin dikkat eksikliği/hiperaktivite bozukluğunda tanı koyma. Psikiyatride Güncel, 6(4), $276-284$.

Ercan, E.S. \& Aydın, C. (2011). Dikkat eksikliği hiperaktivite bozukluğu. Ben hasta değilim: Çocuk sağlğgl ve hastalıklarının psikososyal yönü içinde (s.165-181), Ed: A Ekşi. İstanbul: Nobel Tip Kitabevleri.

Faraone, S. V., Biederman, J., \& Mick, E. (2006). The age-dependent decline of attention deficit hyperactivity disorder: a meta-analysis of follow-up studies. Psychological Medicine, 36(2), 159-165.

Ghanizadeh, A., \& Shams, F. (2007). Children's perceived parent-child relationships and family functioning in attention-deficit/hyperactivity disorder. Child \& Family Behavior Therapy, 29(3), 1-11.

Gonzalez, L. O., \& Sellers, E. W. (2002). The effects of a stress-management program on self-concept, locus of control, and the acquisition of coping skills in school-age children diagnosed with attention deficit hyperactivity disorder. Journal of Child and Adolescent Psychiatric Nursing, 15(1), 5-15.

Gökçen, C., Özatalay, E., \& Fettahoğlu, E. Ç. (2011). Dikkat eksikliği hiperaktivite bozukluğu olan çocukların anne babalarında psikolojik belirtiler ve aile işlevselliği. Çocuk ve Gençlik Ruh Sağllğı Dergisi, 18, 95-104. 
Hodgkins, P., Arnold, L. E., Shaw, M., Caci, H., Kahle, J., Woods, A. G., \& Young, S. (2012). A systematic review of global publication trends regarding long-term outcomes of ADHD. Frontiers in Psychiatry, 2(84), 1-18.

Johnson, J. H., \& Reader, S. K. (2002). Assessing stress in families of children with ADHD: Preliminary development of the Disruptive Behavior Stress Inventory (DBSI). Journal of Clinical Psychology in Medical Settings, 9(1), 51-62.

Johnston, C., \& Mash, E. J. (2001). Families of children with attention-deficit/hyperactivity disorder: review and recommendations for future research. Clinical Child And Family Psychology Review, 4(3), 183207.

Karaman, D., Durukan, İ., \& Kara, K. (2012). Dikkat eksikliği hiperaktivite bozukluğu olan çocukların aile işlevleri ile annelerinin depresyon ve anksiyete belirti düzeyleri. TAF Preventive Medicine Bulletin, 11(6), 741-748.

Kepley, H. O., \& Ostrander, R. (2007). Family characteristics of anxious ADHD children: Preliminary results. Journal of Attention Disorders, 10(3), 317-323.

Kessler, R. C., Adler, L., Barkley, R., Biederman, J., Conners, C. K., Demler, O., ... \& Spencer, T. (2006). The prevalence and correlates of adult ADHD in the United States: Results from the National Comorbidity Survey Replication. American Journal of psychiatry, 163(4), 716-723.

Klein, R. G., Mannuzza, S., Olazagasti, M. A. R., Roizen, E., Hutchison, J. A., Lashua, E. C., \& Castellanos, F. X. (2012). Clinical and functional outcome of childhood attention-deficit/hyperactivity disorder 33 years later. Archives of General Psychiatry, 69(12), 1295-1303.

Martel, M. M., \& Nigg, J. T. (2006). Child ADHD and personality/temperament traits of reactive and effortful control, resiliency, and emotionality. Journal of Child Psychology and Psychiatry, 47(11), 1175-1183.

MEB (2016). Çocuk Gelişimi ve Eğitimi: Dehb ve kaynaştırma. Ankara: T.C. Milli Eğitim Bakanlığı.

MEB (2017). Çocuk Gelişimi ve Eğitimi: Dehb ve eğitim planı. Ankara: T.C. Milli Eğitim Bakanlığı.

Merikangas, K. R., He, J. P., Burstein, M., Swendsen, J., Avenevoli, S., Case, B.,... \& Olfson, M. (2011). Service utilization for lifetime mental disorders in US adolescents: results of the National Comorbidity Survey-Adolescent Supplement (NCS-A). Journal of the American Academy of Child \& Adolescent Psychiatry, 50(1), 32-45.

Merriam, S.B. (2015). Nitel araştırma (Çev. Ed. S. Turan). Ankara: Nobel.

Miles, M.B. \&Huberman, A.M. (2015). Nitel veri analizi (Çev. Ed. S. Akbaba Altun, A. Ersoy). Ankara: Pegem.

Murphy, K. R., Barkley, R. A., \& Bush, T. (2002). Young adults with attention deficit hyperactivity disorder: subtype differences in comorbidity, educational, and clinical history. The Journal of Nervous and Mental Disease, 190(3), 147-157.

National Institute of Mental Health (NIMH), (2018). Attention deficit hyperactivity disorder. https:// www.nimh.nih.gov/health/topics/attention-deficit-hyperactivity-disorder-adhd/index.shtml Sayfasından erişilmiştir.

Neihart, M. (2003). Gifted children with attention deficit hyperactivity disorder (ADHD). ERIC Digest. Retrieved From https:/eric. ed.gov/?q=Gifted+Children+with+Attention+Deficit+Hyperactivity+Disorder.\&id=ED482344

Özmen, S. K. (2010). Okulda dikkat eksikliği ve hiperaktivite bozukluğu (DEHB). Mersin Üniversitesi Eğitim Fakültesi Dergisi, 6(2), 1-10. 
Reimherr, F.W., Marchant, B.K., Strong, R.E., Hedges, D.W., Adler, L., Spencer, T.J., West, S.A., \& Soni, P. (2005). Emotional dysregulation in adult ADHD and response to atomoxetine. Biol Psychiatry, 58 (2), 125-131.

Schachar, R., \& Tannock, R. (2002). Syndromes of hyperactivity and attention deficit. In Child and adolescent psychiatry (s. 399-418.), Eds: Rutter M., Taylor E. Oxford: Blackwell Science.

Shur Fen Gau, S. (2007). Parental and family factors for attention-deficit hyperactivity disorder in Taiwanese children. Australian \& New Zealand Journal of Psychiatry, 41(8), 688-696.

Soroa, M., Gorostiaga, A., \& Balluerka, N. (2016). Teachers' knowledge of ADHD: Relevance of training and individual perceptions. Revista de Psicodidáctica, 21(2), 205-226.

Soykan Aysev, A., \& Erdoğan Bakar, E. (2010). Ergende dikkat eksikliği hiperaktivite bozukluğu. Kognitif nörobilimler içinde (s.403-416), Ed: Karakaş S. İstanbul: Nobel Tip Kitabevleri.

Sucuoğlu, B, \& Akalın, S. (2010). Kaynaştırma sınıflarına alternatif bir bakış: Çevresel davranışsal değerlendirme ile öğretimsel özelliklerin incelenmesi. Ankara Üniversitesi Eğitim Bilimleri Fakültesi Özel Eğitim Dergisi, 11 (1), 19 - 37.

Temel, A. B. (2013). İlköğretim sınıf öğretmenlerinin çocuklarda dikkat eksikliği ve hiperaktivite bozukluğunu tanıma yeterlilikleri. Dokuz Eylül Üniversitesi Hemşirelik Fakültesi Elektronik Dergisi, 6(4), 207-213.

Toros, F. (2003). Dikkat eksikliği hiperaktivite bozukluğu hakkında öğretmenlerin bilgileri ve tutumları. New/Yeni Symposium Journal, 41(4), 165-168.

Turgay, A. (2004). Aggression and disruptive behavior disorders in children and adolescents. Expert Review of Neurotherapeutics, 4(4), 623-632.

Voeller, K. (2004). Attention deficit hyperactivity disorder (ADHD). Journal of Child Neurology, 19 (10), 798-814.

Wasserstein, J. (2005). Diagnostic issues for adolescents and adults with ADHD. Journal of Clinical Psychology, 61(5), 535-547.

Yıldırım, A. \& Şimşek, H. (2016). Sosyal bilimlerde nitel araştırma yöntemleri. Ankara: Seçkin. 